\title{
HEMORRHAGES INTO THE PELVIC CAVITY OTHER THAN THOSE OF ECTOPIC PREGNANCY*
}

\author{
By Richard R. Smlth, M.D., F.A.C.S., Grand Rapids, Mich.
}

$\mathrm{T}$ HAT ectopic pregnancy is the most frequent cause of hemorrhage into the pelvic cavity is a well-established fact. That there may be, however, other causes for such hemorrhage is something which every surgeon of wide experience has had occasion to learn. A considerable literature likewise affords testimony to the same. An experience with a case of hemorrhage from a ruptured Graafian follicle and several instances in which blood was found in the pelvic cavity, have led me to seek further enlightenment from the literature. It is the result of this investigation that I shall attempt to sum up for you. First, however, I wish to cite the case referred to.

A. L., single, aged twenty-four, gave the following history: As an infant she had rickets and did not walis until she was three and a half years old. From that time on she was robust until four years ago, at which time she had some acute illness of uncertain nature, lasting a week, during which she lost many pounds in weight. She has been below par physically since that time. During the past two years she has had oceasional attacks of vomiting (usually one or two hours after eating), lasting altogether from one to three weeks. Shortly after the illness mentioned above she had an attack of pain and soreness in the right side, which lasted about a week. Two years later a similar attack.

Present attack began six hours before operation, with severe acute ahdominal pain, which radiated through to the rectum. This pain was so sevore that she was "all doubled up" as she expressed it, and perspired freely. 'The acute attack lasted about an hour and then gradually eased off. She was seen about two hours after the onset. There was some tenderness over the lower abdomen, with the principal point low down on the right side. There was no distinct rigidity but the cutaneous reflex was absent in the right lower quadrant. By rectal examination great tenderness was found in the right euldesac. Puige and temperature were not disturbed. With the history of previous attacks and the present history and findings, a diagnosis of acute appendieitis was made, and uperation advised.

On opening the abdomen through an appendiceal incision a small amount of sangruinous-fluid escaped. The appendix, which we had supposed was directed down into the pelvis, lay to the outer side of the cecum, extending well ap toward the lidney. It was kinked and bound down by adhesions, but there was no sign of recent trouble. It was freed and removed. Further examination revealed blood coming from the pelvis. Since a more thorough examination was necessary, a median incision was made and the pelvis examined. The uterus was normal in size and position. Both tubes and the left ovary were normal. The right ovary was as large as a walnut and presented a ruptured Graafian follicle the size of a hickory nut, which had evidently been the source of the bleeding. There were about two or three ounces of fresh blood. The follicle was dissected from the ovary and the edges united. Patient made a good recovery.

Dr. Warthin (pathologist) of Ann Arbor reported that the specimen "shows only a normal hemorrhagic follicle, with early development of the corpus luteum, 26, 1920 .

"Read at the Forty-ffth Annual Meeting of the Arserican Gynccological Society, Chicago, May 24- 
nothing pathologic. We have had similar cases thought to be ectopic and showing nothing more."

Dr. Warthin in further correspondence says that since 1895 he has had five similar cases in the diagnostic service of the Pathologic Laboratory of the University of Michigan. Complete histories of the cases were not then available, but in all the condition has been thought to be ectopic gestation. Two of these women were unmarried, had exposed themselves to the danger of conception; in the other cases there was also a fear of pregnancy. The patients were all young women, one or two periods had been missed, there was nervous excitement and worry, and then symptoms suggesting ectopic pregnancy. Large, apparently normal hemorrhagic follicles were found, with amounts of blood varying from several teaspoonfuls to several tablespoonfuls in the cavity. Histologic examination showed no evidences of pregnancy. Dr. Warthin's experience with the condition is interesting as showing the relative rareness of the condition and the suggestion that mental excitement and worry may sometimes have some relalation to it..

The number of such cases found in the literature is a considerable one. Cases very similar to mine are reported by Adams, ${ }^{1}$ Bartelo, ${ }^{3}$ Bender, and Marcel, ${ }^{5}$ Benthin, ${ }^{6}$ Bertkrau, ${ }^{7}$ Bonneau, ${ }^{11}$ Bookman, ${ }^{10}$ Boveé, ${ }^{\circ}$ Cranwell, ${ }^{13}$ Edgard, ${ }^{15}$ Engstrom, ${ }^{16}$ Forssner, ${ }^{18}$ Hind, ${ }^{21}$ Kober, ${ }^{23}$ Ladinski, ${ }^{25}$ Lee, ${ }^{26}$ Lockyear, ${ }^{29}$ Luken, ${ }^{30}$ Novak, ${ }^{34}$ Ohman, ${ }^{36}$ Pfeilsticker, ${ }^{37}$ Primrose, ${ }^{30}$ Roll, ${ }^{40}$ Romme, ${ }^{41}$ Simonds, ${ }^{44}$ Tartansen, ${ }^{45}$ Taylor, ${ }^{40}$ and Winiwarter. ${ }^{52}$

Dr. F. C. Warnshuis has kindly furnished me with the report of a case of this kind coming under his observation.

M. K., school girl, aged fourteen, had had the usual diseases of childhond but no serious illnesses. Menstruation beginning at the age of twelve, had been regular, occurring every 28 to 30 days, and in every way normal. She was a welldeveloped girl and had the appearance of seventeen years. Her present illness began November 27, 1913. While at school she stated that she had cramps in the abdomen. She came home complaining of abdominal pain and nausea. After reaching home she vomited. Her symptoms increased and Dr. Warushuis saw her about nine-thirty that night in consultation.

The abdomen was everywhere tender, but extremely so in the right lower quadrant, and there was slight distention. By the rectum a great deal of pain was elicited by pressure in the right culdesac, and there was a certain amount of bogginess. There was a very slight bloody discharge. Temperature $98^{\circ} \mathrm{F}$., pulse 110. A clinical diagnosis of acute appendicitis was made, but because of having had a somewhat similar case two weeks before (see bibliography) a ruptured Graafian follicle was thought of. Operation was advised and carried out that night.

Right rectus incision. On opening the peritoneum blood was discovered in considerable quantities. The right tube and ovary were brought up. The latter was ruptured and an active hemorrhage was taking place. The ovary was removed. The appendix was normal. Abdomen cleansed of blood and closed. Puise at close of operation 136 , but condition was otherwise good. She made an uneventful recovery. Pathologic diagnosis of ruptured follicle, no decidual or placental tissue.

The histories of these cases read very much alike. They have occurred usually (though not always) in young women, just before, during, or just after menstruation. The diagnosis has either been acute appendicitis or rup- 
tured ectopic pregnancy, and the real condition has not been learned until the abdomen was opened. A ruptured Graafian follicle has been found as the only source of hemorrhage. The loss of blood has varied considerably, in a few instances it has been large enough to cause very serious symptoms. The pathologic report has shown no change in the blood vessels, or anything to distinguish the ovary or follicle from the normal. It is not difficult to conceive that if one had this possibility in mind a more or less positive diagnosis might be made before operation. Such an attack occurring about the time of a menstrual period in an unmarried woman might lead one to at least suspect that the case was one of ruptured Graafian follicle. If the symptoms were mild one might even defer operation under careful watching. However, at the present time operation would seem to be the safer plan, both because of the uncertaintics of diagnosis and the possibilities of continued hemorrhage. I think these cases of acute hemorrhage from a ruptured Graafian follicle - or corpus luteum should be grouped by themselves, because they are apparently not caused by any pathologic condition of the ovary or pelvic organs, and because they are emergencies which call for immediate clinical attention and usually operation.

Two variations from the usual severe Graafian follicle bleeding should be mentioned. One occurs in herrophilic subjects. An inleresting case of this kind has been published by Warnshuis. ${ }^{49}$

The patient was a girl of seventeen who gave a history of having had an attack of appendicitis one year previously. At this time she had apparently been very ill. Menstruation had been regular but attended with some pain and clots. The family history was negative as regards hemophilia. On January twelfth, 1912, while attending school, she was seized with severe pain in the abdomen and some nausea, but no faintness or dizziness.

When seen later there was general abdominal tenderness, but more marked in the right lower quadrant and there was muscular rigidity. This with the history of pain and nausea made acute appendicitis a probable diagnosis, and she was accordingly operated at once. At the time of her operation her pulse was 84 , temperature $99.4^{\circ} \mathrm{F}$.

Upon opening the peritoneum there was a gush of fresh red blood and clots. The right tube and ovary were normal, the left ovary was ruptured and was removed. An appendix (surrounded by adhesions) which had evidently been the seat of a former appendicitis was removed. Pulse at the close of operation 140.

Pathologic report: "ovary was normal in size. There is a ruptured follicle. There were multiple hematomas but no decidual cells."

On the third day the patient had a severe nasal hemorrhage, controlled by packing the nostrils. The morning of the eighth day the nurse reported that her dressings were soaked with blood. Investigation showed that the blood had come from the lower end of the abdominal wound. The hemorrhage continued and she was taken to the opcrating room. The wound was reopened under local anesthesia down to the peritoneum. There was marked capillary oozing, and a small artery was bleeding in the right rectus. This was tied. Patient died that night.

Another variation worthy of note is a case of hemorrhage which oceurred from a corpus lutcum after operation. The case is reported by Ferguson. ${ }^{17}$ 
The patient was thirty-seven years of age and suffered from a fibroid. He did a supravaginal hysterectomy, the operation being a simple one. Both ovaries and tubes were left behind, as they were quite healthy. At the time of the operation a large corpus luteum was noticed on the surface of the right ovary, and attention was called to it merely as a point of interest. The operation was done in the morning at nine-thirty, the patient leaving the table in good condition. At five that afternoon the nurse noticed that the patient looked rather pale. At eight-thirty that evening the pulse had risen to 130 , was very weak, and there were marked signs of hemorrhage.

The wound was re-opened under anesthesia and a large quantity of clotted and fluid blood found in the abdominal cavity. After clearing the field Dr. Ferguson made an examination of the pelvis and found that the hemorrhage had occurred from the corpus luteum seen at operation. The appendage was removed and the patient recovered. The case is of unusual interest, showing the possibilities of hemorrhage from this source after hysterectomy with retention of the ovaries, the operation as it is commonly performed today. One might hesitate in the light of his experience to leave uncared for an ovary with a large corpus luteum in it.

Excluding tubal pregnancy, there can be no question but that the ovaries more frequently give rise to intraperitoneal bleeding than any other of the pelvic organs or structures. There is apparently a good reason for this. They have little firmness, their blood supply is large, and in a constant state of morphologic and functional change from puberty to menopause. There is menstruation each month and ovulation with extrusion of the ovum. At this time the follicle fills with blood. At menstrual times the pelvic organs are congested, and to a lesser degree during coitus. Displacements of the organ or large tumors in the pelvis are apt to cause blocking of the return circulation and thus hemorrhage from the ovaries is favored.

These explanations are not altogether satisfactory when applied to individual cases. The real cause of the hemorrhage in most instances remains unexplained. We are in doubt as to the cause and we are often equally so in regard to the exact origin of many hemorrhages and the sequenec of events that produce this condition. One needs only to read the pathologic reports to confirm this. There seems but little unanimity of opinion as to the starting point. Once a hematoma has formed in the ovary, the pressure causes absorption and distortion of the delicate surrounding tissues, and makes it difficult or impossible to understand the condition in detail.

Clinically we may perhaps divide the cases of ovarian hemorrhage into three groups-first, those due to rupture of the normal Graafian follicle or corpus luteum; second, those occurring from a condition known as hematoma ovarii; and third, those occurring in ovarian cysts (or solid tumors). Although perhaps each case cannot always be so definitely elassified, this offers on the whole I believe a convenient clinical grouping. I have already discussed the first group. Of the second-that of hematoma ovarii, the following case is a good instance.

M. N., aged twenty four, student. Of enteroptotic type and poorly nourished. Has a goiter with slight toxic symptoms. A question in the case as to an earlier tuberculosis of the lungs, although there are no sigus apparent to ordinary examination. Has always had severe dysmenorrhea, compelling her to go to bed for a day or two. She has some bladder irritability and con- 
siderable vaginal discharge at times. The uterus was retroverted and fixed, and there was a soft, fixed mass in the left culdesac. On opening the abdomen the first thing that attracted attention was a little free bloody fluid in the culdesac. The omentum had evidently absorbed some of this, for it was dark with blood. The left ovary was the size of a lemon and adherent. It was released with the uterus. Both tubes were normal, and the right ovary, although resembling somewhat in appearance the left, was normal in size and free of adhesions. On releasing the left ovary a quantity of chocolate colored fluid escaped. There were numerous small cysts (follicles) in the ovary containing dark material. The appendix was entirely normal. The ovary was removed, leaving the right one, and correcting the displacement of the uterus by an intramural shortening. The patient has been markedly relieved by the operation.

No reason can be ascribed for the condition of the ovary (the pathologist reported "hemorrhagic cyst of ovary"). There was no sign of any tubal or other infection. It is hardly conceivable that the simple displacement could have accounted for it. Here was hemorrhage not only into the ovary itself, but from it as well. The process had produced adhesions.

Wolf ${ }^{53}$ has reported eight such cases of hematoma of the ovary. In four of his cases the condition was complicated with myoma of the uterus, one with tubereulous peritonitis, and in two with pelvic peritonitis.

Meriel ${ }^{32}$ reports a case of dysmenorrhea in a patient fourteen years of age in whom this condition was found. No reason for the occurrence could be discovered. There are many other cases of this group reported in the literature. There is chronic retention of blood in the follicles. The disturbance is first seen in the vascular tunica interna of the distended follicles, hemorrhage into the follicle follows. The hematoma presses upon the surrounding ovarian tissue and hemorrhage takes place into the stroma. The affected organ is surrounded by adhesions.

The condition is usually associated with some other, as Wolf has stated, to which it can be secondary. We have all seen it associated with pelvic tumors. These hematomas rarely give rise to severe hemorrhage. In many of the cases no cause for the condition can be traced, as in the case of Meriel and my own.

The third group is one in which cysts of various size give rise to hemorrhage either into the tumor itself or externally into the abdominal cavity. The cause may be a torsion of the pedicle, or traumatism, or perhaps it is not discovered. When cysts of any size are fixed in the pelvis by adhesions, one very likely cause of hemorrhage has seemed to me to be trauma. Struins or falls might conceivably produce it. I personally know of one case where such a cyst was ruptured from coitus, though in this particular instance without hemorrhage. Bleeding into an ovarian cyst may give rise to symptoms simulating ectopic preguancy-a case of my own is in point.

K. P., aged twenty-seven. No children, but was operated five years previously for right tubal pregnancy. At this operation, which was performed somc time after the rupture had taken place, there were many adhesions, and in freeing the left tube for inspection the fimbriated extremity was torn away. The rest of the tube was left in situ, with the hope that it might allow pregnaney. The right was removed, leaving two good ovarics. 
In November, 1919, she was suddenly seized with pain in the lower abdomen, resembling somewhat her former attack. Pain decreased slowly-no signs of shock. At the end of about six days an examination revealed a fixed mass in the culdesac extending to the left pelvic wall. A repetition of her former trouble was considered.

At operation the appendage was found surrounded by firm adhesions, the ovary containing a cyst somewhat larger than a tennis ball. It was filled with blood clot. The tube was closed and adherent to the surface. The appendage was removed, leaving a healthy right ovary. Recovery.

Michon ${ }^{33}$ reports a case of torsion of the pedicle of a solid ovarian tumor, with hemorrhage into the abdominal cavity. (Hemorrhage into a cyst under the same conditions is not uncommon.) Le Moinet ${ }^{27}$ reports a case of rupture of the pedicle of a dermoid cyst. Jayle ${ }^{2 s}$ gives an extensive bibliography of hemorrhage from the ovary, and I would refer those interested to it. Many of the best articles appear in the bibliography appended to my paper.

Hemorrhage from a nonpregnant tube is rare. I can find no instanee in the literature of the last twenty years in which a violent hemorrhage has occurred that could not be questioned. Some bleeding into the tube with clots, however, may occur, but I believe is uncommon. Bazy ${ }^{4}$ goes into the pathology of three such instances, and I have in mind one instance in which I found a small amount of blood in a tube, the result of an old Neisser infection. Some bleeding into a tube the subject of torsion I have seen in a few instances.

An interesting group with hemorrhage into the abdominal cavity is formed by fibroids. This is aside from the hemorrhage from an ovary that is associated with such a tumor. Wallace ${ }^{54}$ eites seventeen cases (and five doubtful ones) in which this occurred. The bleeding has often been a serious one and the mortality has been very high ( 25 per cent). The hemorrhage has usually come from a vein or sinus on the surface of the fibroid by the establishment of an opening in some weak spot in the vessel wall. The yielding of the weak spot has been caused by some sudden effort on exertion, or as a result of increased tension in the myoma itself, consequent to torsion of the pedicle of a pedunculated tumor. In four cases the vessels were injured as a consequence of laceration of a solid myoma or in the rupture of a cystic one; in one instance by an eroding ulceration caused by pressure of a bony projection against the tumor.

Gerstenberger ${ }^{20}$ reports the case of a nurse who had been in the habit of lifting a heavy patient. She was seized with sudden faintness and at operation there was found a rent in the uterus from which severe hemorrhage had occurred. The myoma was removed and the patient recovered.

Wallace discusses the question of treatment of these cases. He suggests that in view of the very high mortality control of the hemorrhage alone should be undertaken, the removal of the tumor to be left to a more favorable time.

It is surprising that accidents of this kind are not more frequent. I have had no personal experience with them, but I very recently had reported to me by Dr. Wynand Pyle of Grand Rapids a case coming under his observation, in which this accident probably occurred. The patient was a maiden lady, over 
fifty years of age. She fell accidentally on the street, was helped to her home. She became faint and short of breath. He saw her soon after and an examination revealed a hard tumor, evidently a fibroid, in the lower abdomen. She gave distinct evidence of a hemorrhage and died at the end of three hours, unoperated. No autopsy was allowed.

\section{REFERENCES *}

1.tams, E.: Trenomhage from a Corpng Lutem Syst, Brit. Med. Jour, London, 1913, 1, 712.

Arrivita, M.: Les hémolragies génitales d'origine ovarienne; discussions pathogéniques et thérapeutiques. Gaz. d. hôp., Paris, 1911, lxxxvii, 1371-1411.

3Bartelo, C. D.: Can Rupture of the Corpus Luteum Cunse Severe Intruperitoneal Hemorrhage Ugeskr. f. Laeger., Kobenh., 1919, Ixxxi, 935-946.

Bazy, L.: Des hémorragies de la trompe non gravide. (la pachysalpingite hémorragique). Rev. de Gynec. et de Chir. Abd., Paris, 1910, xv, I, 91, 2 pl.

Bender and Mareel: Intraperitoneale Blntung infolge Ruptur einer haemorrhagisehen Ovarialcyste, Bull. et mém. de la Soe. Anat. de Paris, July, 1904.

BBenthin: Henatocele als Folge einer geplatzen Corpus luteum Cyste, Monatschr. f. Geburt. und Gynak, Berlin, 1913, xxrii, 532.

`Bertkrau: Schwere Blutung in die freie Bauchlölile aus einem Ovarium. Charité-Ann., Berlin, 1910, xxxiv, 571.

sfsoveé, .T. Wesley: Tubal and Ovarian Hemorrhage, Surg., Gynec. and Obst., Chieago, 1919, 1, xxviii, 117.

sBvuctey, F. J.: Contribution a l'etude des kystes Hematiques de l'ovaire. Thèse, Bordeaux, 1903.

10Bookman, M. R.: Rupture of a Corpus Luteum with Free Intraperitoneal Henorrhage, Med. Rec., New York, 1914, lxxxvi, 184.

11Bonneau, R.: Hemorrhagie intraperitoncal recidivante par ruptur d'un follicle de Graaf., Paris Chirurg., 1912, iv, 1101-05.

12Cantoni, V.: Unterguchungen über Ovarialblutungen, Arch. f. Gynäk., Berlin, 1914, ciii, $564-574$.

${ }^{3}$ Cranwell, D. J.: Inondation peritoneale par rupture d'un follicle de Graaf, Ann. de gynee. et d'obstet., Paris, 1912, 2 s., ix, 226.

14Dubreuil, G., and Regaud, C.: Sur les follicules ovariens hèmorragiques et sur mécanisme de déhiscence des follieles. Compt. rend. Sceances et Memoires de la Soe. de biol., Paris, 1909, Ixxvii, 828830.

15Edgard, J.: Ruptured Hematoma of the Left Ovary, the Cause of Pelvic Hematocele, Glasgow Med. Jour., 1900, liii, 294.

16Engstrom, Z.: Die Entstehung von grossen intraperitonealen Blutergüssen bezw. von Hematocele durch Blutung aus einem Corpus Luteum. Mitt. a. d. Gynäk. Klin. d. O. Engstrom in Helingsfors, Berlin, 1907-08, vii, 147-155.

17Ferguson, James Haig: Case of Fibroid of the Uterus (Showing Unusual Form of Cystic Ohange) Removed by Supravaginal Hysterectomy, Where Severe Post-operative Hemorrhage Oceurred from a Corpus Luteum, Necessitating Reopening of the Abdomen and Removal of the Ovary, Eding. Ohst. Trans., 1911-12, xxxvii, 307 .

18F'orssner, H.: Können grosse intraperitoneale Blutungen aus Graafsclien Follikeln oder Corpus Luteum Bildungen ohne Vorhandensein von Schwangerschaft entstehen: Arch. f. Gynäk., Berlin, 1916, ev, 74-106.

10Gabriel, A.: Ueber die Entstehung der hematocele retrouterina aus Ovarialblutungen, Arch. f. Gynäk., 1901, Ixiv, 449.

soGerstenberger, E.: Schwere intraperitoneale Blutung aus seiclichen Venen des Uterus bej subserösem Myoma des Fundus, Zentrallıl. f. Gynäk., 1916, No. 40.

21Find, W.: Sudden Hemorrhage from the Ovary, Brit. Med. Jour., 1905, ii, 189.

2zJayle: Pelvic Hematocele from Rupture of Blood Cyst of Ovary, Revue de Gynec. et de Chir. Abdomen, 1909, xiii, 185-222; Abstracted in Brit. Med. Jour., 1909, xvi, 50.

2.3 Kober: Hematocele Retrouterina olme Extrauterine Gravidität. Zentralbl. f. Gynäk., 1901, Nr. 39, p. 1.07 .

24Kynoch, J. A. C.: Pelvic Hematocele from Ruptnre of a Bloor Cyst of the Ovary, Jour. Obst. and Gynec. of the Brit. Emp., London, 1913, xxiii, 304.

25Ladinski, I. J.: Bleeding from a Corpus Luteum, Am. 'Jour. Obst., 1910, lxii, 487.

26Lee, J. A.: Hemorrhagic Cyst of the Ovary Simulating Ectopic Pregnancy, Brooklyn Med. Jour., 1905, xix, 209.

*This bibliography includes only the literature appearing since 1900 . Pefore that time the accounts for the most part do not clearly establish the fact that the hemorrhage was not due to ectopic pregnancy, and it was thought best to omit them altogether. 
2iLe Moinet: Rupture spontanee du pedicle d'un kyste dermoide de l'ovaire. (Rapport de F. Leguen). Bull. et mém. Soc. de Chir. de Paris, 1912, n.s., xxxviii, 315-317.

28Leriche, R., and Blane-Perducet, M.: Hémorragie pelvienne intra-peritoneale diffuse par ruptur d'un kyste hemorragigue. Revue de Gynec. et de Obst., Par., 1911, 2 s., viii, 529-5.54.

29Lockyear, Cuthbert: Pelvic Hematocele of Ovarian Origin, Proc. Roy. Soc, London, 1910, viii, Part 2, p. 106. (Obst. and (Grn. Sec.); also Jour. Obst. and Gynec. Brit. Fmp., 1910 , xvii, 253 .

30Luker, S.: A Case of Rupture of a Iremorrhagic Corpus Luteum into an Intraligamentary Oyst, Resembling Ruptured Ectopic Pregrancy, Lancet, London, 1912, ii, 1075.

31Martin, P. F.: Tubo-ovarian Hematocele Simulating Ectopic Gestation; Surgical Conservatism in Dispute, Jour. Indiana Med. Assn, 1910, pp. 481181.

32Meriel: Ovarian Hematoma Causing Dysmenorrhea, Soc. Obstet., Toulouse, 1911, xiii, No. 2, p. 84. Abstracted in the Jour. Obst. and Gynec. of Brit. Emp., 1911, ii, xx, 139.

33Michon, E.: Tumeur solide de l'ovaire; torsion du pedicle; hemorragie intraperitoneale; laparotomie; guerison apres embolus pulmonaires. (Rapport de Souligoux). Bull. et mém. Soc, de Chir. de Par., 1909, n.s., xxxy, 1072-1077.

34 Fovak, E.: Abdoninal Hemorrhage of Orarian Origin with Report of a Case Due to Rupture of a Small Follicular Cyst, Jour. Am. Med. Assn., 1917, 1xviii, 1160-1162.

35Novak, E.: Hematoma of the Orary, Including Corpus Luteum Cysts, Bull. Johns Hopkins Hosp., 1918, xxxviii, 736-738.

s6hman, K. H.: Ovarian Hematoma and Ovarian Hemorrhage, Dnodecim Helsinki, 1913, xxix, $55-76$.

37Pfeilsticker, W.: Ueber lebensbedrohlisehe intraperitoneale Blutung aus einem Graafschen Follikel. Med. Cor. Bl. d. Würtemb. ärtzl. Landesver., Stuttg., 1913, 1xxxiii, 535-536.

38 Poulain, J.: Hematocele retro-uterine sans rupture de la trompe. Rev. mens. de gynee., d'obstet. et de peciat., Paris, 1910, vo 76-78.

39Primrose, A.: Hemorrhage into the Peritoneal Carity, Caused by Accidental Rupture of the Ovary, Trans. An. Surg. Assn., 1912, xxx, 599-607.

toRoll, J.: Life Endangering Bleeding from the Ovary, Norsk. Mag. f. Laegevidensk., Kristiana, 1911, S.R., ix, $27-31$.

41Romme, Madeline: Hemorrhagie abdominale d'origine ovarienne. Ann. de gynec. et d'obstel., Paris, 1917, 2 s., xii, 736-735.

42Rossear, E.: Hemorragies ovariennes, Jour. Med. de Bruxelles, 1903, viii, 785.

${ }_{3}$ Seadorff, M.: Hematoma ovarii dets fremkonist og kliniske he lydoning Hosp. Tid., Kbenh, 1913, 5 R. I., vi, 73-93, 1 pl.

4. Simonds: Peritonealblutung aus einem geplatzen Graafschen Follikel. München. med. Wehnschr., 1917, lxiv, 1565.

45Tartansen: Pelvic Hematocele; Uterine Fibroid Disease; Rupture of Haematic Cyst of Ovary; No Ectopic Gestation, Jour. Obst. and Gynec., Brit. Emp., London, 1910, xvii, 246.

${ }_{46}$ Taylor, G.: Some Uncommon Causes of Pelvic Hemorrhage in Women, Practitioner, London, 1918, ci, 37-39.

47Trassman: Ueber Eienstockblutungen, BerI. klin. Wchuschr., 1917, liv, 567.

48Walters, C. H.: Hemorrhage into an Ovarian Cyst, Simulating Éctopic Pregnancy, Jour. Am. Med. Assn., 1918, 1xx, 295.

49Warnshuis, F. O.: A Report of a Oase of Ruptured Ovary, with Large Intra-abdominal Hemorrhage and Symptoms of Recurrent Appendicitis, Phys, and Surg., Ann Arbor and Detroit, 1912, xxir, 123.

50 Whitehouse, B.: Hemorrhage into the Orary, Associated with Severe Dysmenoprhea, Jour. Obst. and Gynec. Brit. Emp., London, 1914, xxvi, 152-154.

5iWilson, H. W.: A Case of Hematoma of the Ovary, Simulating an Attack of Appendicitis, Lancet, London, 1905, i, 1196.

5zWiniwarter: Retrouterine Hematocele Due to Bleeding from a Degenerated Ovary, ztschr. f. Geburt. und Gynäk., 1911, lxviii.

53Wolf, E. H.: Ueber Haematoma Ovarii, Arch. f. Gynäk., 1908, 1xxxiv, 211-243.

5.Wallace, A. .T.: Jutraperitoneal Hemorphage in Cases of Fibromyomata of the Uterus, Jour. Obst. and Gynee. Brit. Emp., London, 1910, xviii, 357.

METE BUILDING.

(For discussion, see p. 302.) 